\title{
Water-Quality and Related Aquatic Biological Characterization of Fish Creek, Teton County, Wyoming, 2007-2011
}

\section{Introduction}

Fish Creek, in western Wyoming near the town of Wilson (fig. 1), is a key feature in the area because it is used for irrigation, fishing, and other recreation, and adds scenic value to properties it runs through. Public concern about nuisance growths of aquatic plants in Fish Creek has been increasing since the early 2000 s. To address these concerns, the U.S. Geological Survey, in cooperation with the Teton Conservation District, began studying Fish Creek in 2004 to describe the hydrology of the stream and later (2007-11) to characterize the water quality and the biological communities.

In particular, the study was designed to address three specific questions:

- Is algal growth in Fish Creek typical for a stream of its size and geographic area?

- Are nutrients entering Fish Creek from nearby land use?

- What is the quality of the water in Fish Creek and the health of its biological communities?

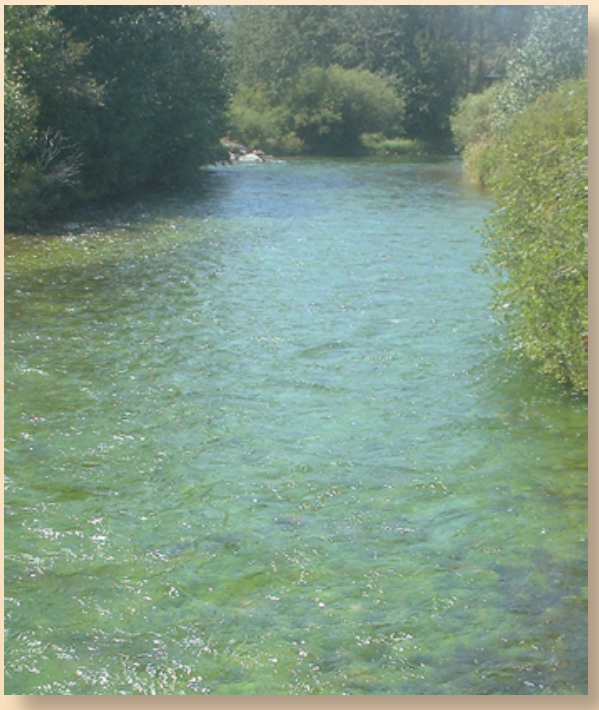

Green hue in stream primarily from the macroalgae Cladophora at site A-Wck, Fish Creek at Wilson, Wyoming.

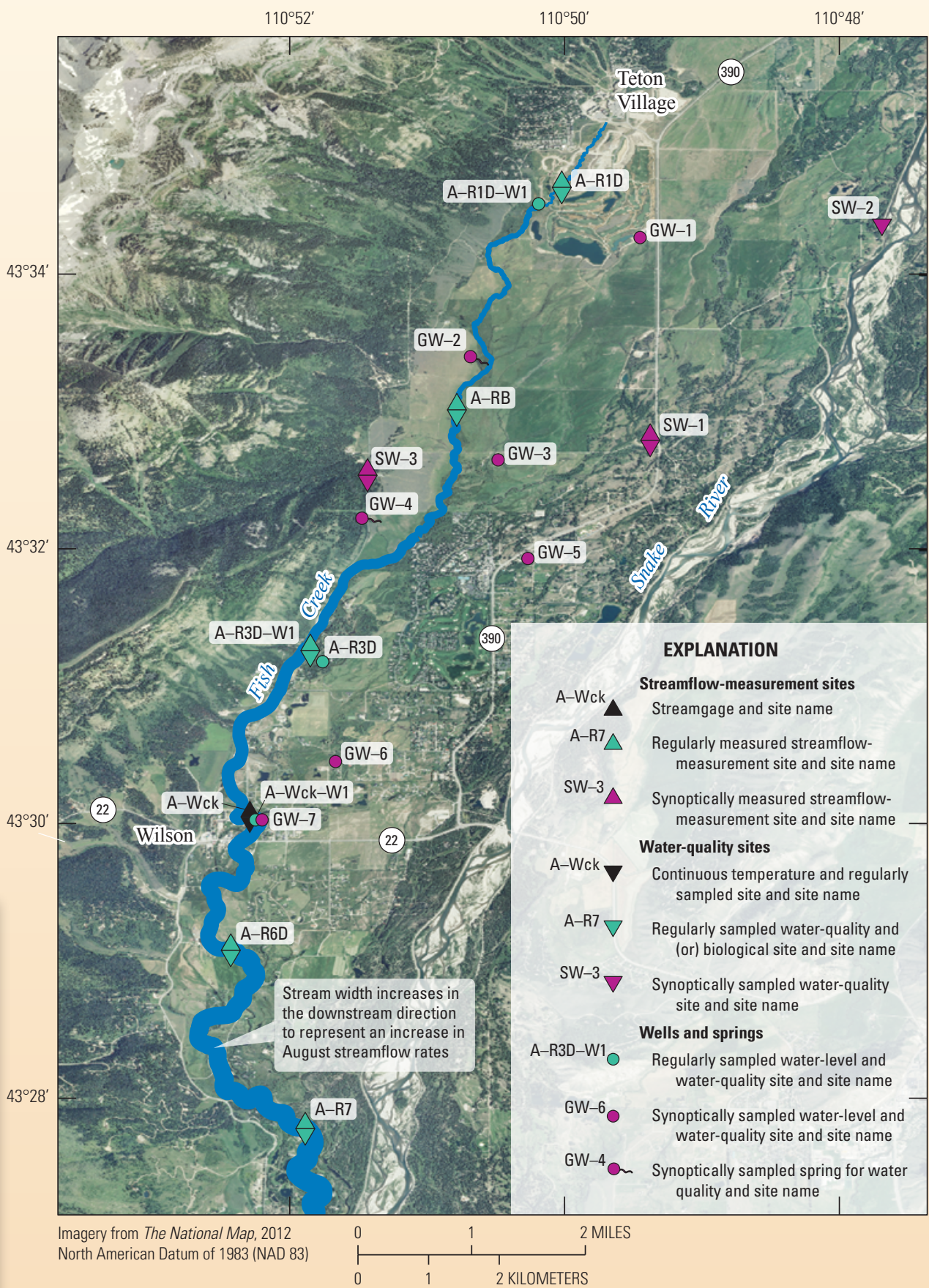

Figure 1. Surface-water and groundwater sampling sites located on Fish Creek from the northern part of the valley near Teton Village, where Fish Creek begins having a defined channel, to just upstream from where Fish Creek begins to mix with waters from the Snake River. Land use in the Fish Creek watershed included summer and winter recreation in forested areas, summer cattle grazing in pastures, and small-acreage and urban housing development (Eddy-Miller and others, 2013). 


\section{Surface-Water and Groundwater Interaction}

During 2004-2006, the focus of the study was understanding the hydrology of Fish Creek, in particular, the interaction (or exchange) between surface water and groundwater (Wheeler and Eddy-Miller, 2005; Eddy-Miller and others, 2009). Findings from this study, as well as other findings (Nelson Engineering, 1992), are summarized in figure 2 to show how streamflow changes in Fish Creek and where the input of water, both streamflow and groundwater, is coming from during the month of August (a month of particular importance regarding algal growth).
Regardless of the time of year, Fish Creek generally gains flow from groundwater discharging into the stream along its length. Depending on the time of year, groundwater constitutes the primary upstream source of water in different parts of the creek. During summer, groundwater provides much of the flow in the upper reach of Fish Creek, near Teton Village, and during winter, groundwater typically provides enough water to keep Fish Creek free of ice. At Wilson, a U.S. Geological Survey streamgage on Fish Creek (13016450, site A-Wck) has recorded flow in the river every 15 minutes since 1994 (U.S. Geological Survey, 2013).

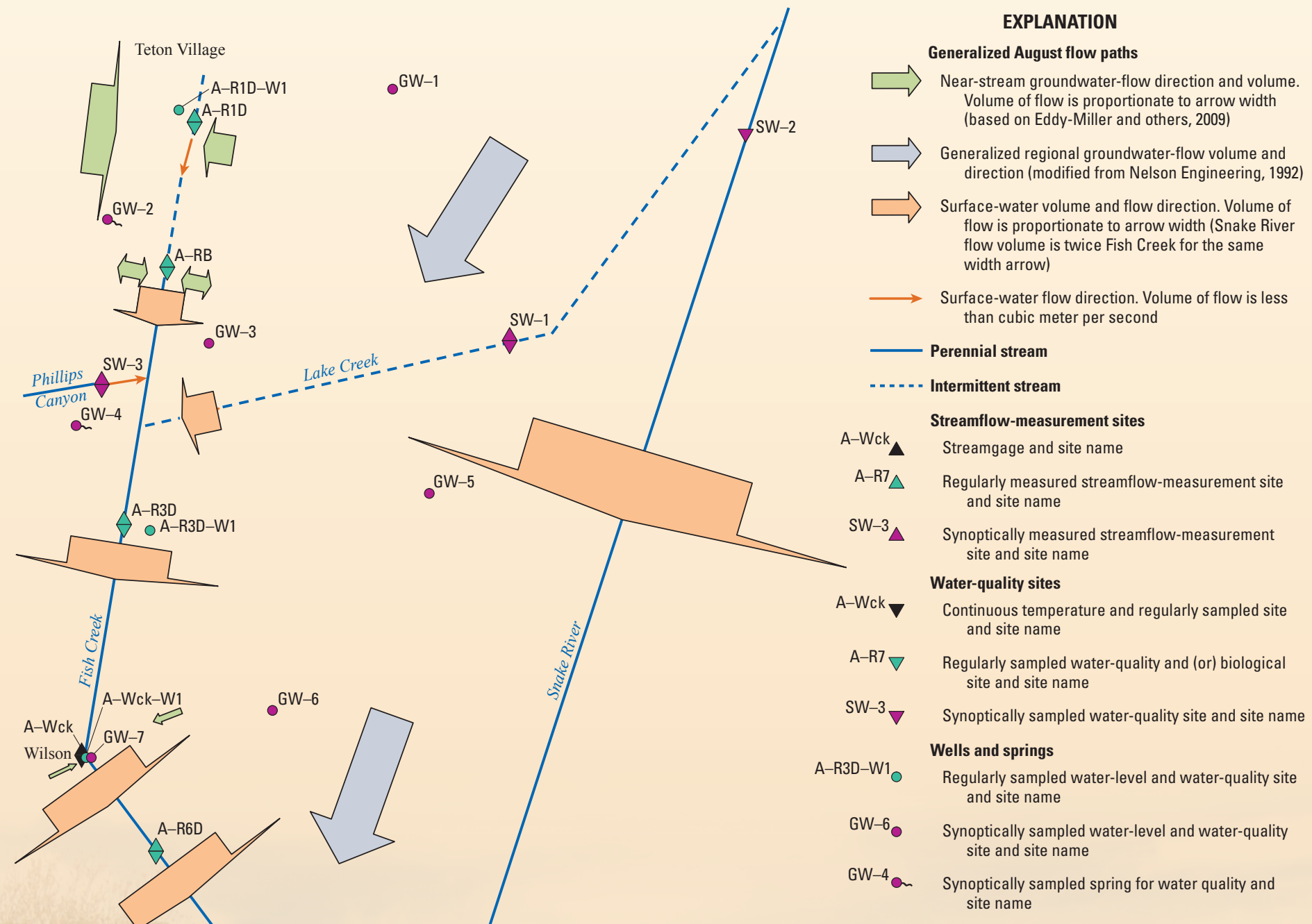

Figure 2. Streamflow in Fish Creek increases because of tributary inputs, snowmelt and rain runoff, and groundwater inflow. Groundwater inflow into Fish Creek sustains streamflow during winter in perennial sections of the stream and is a large component of streamflow in intermittent sections of the stream in summer (Eddy-Miller and others, 2013). 


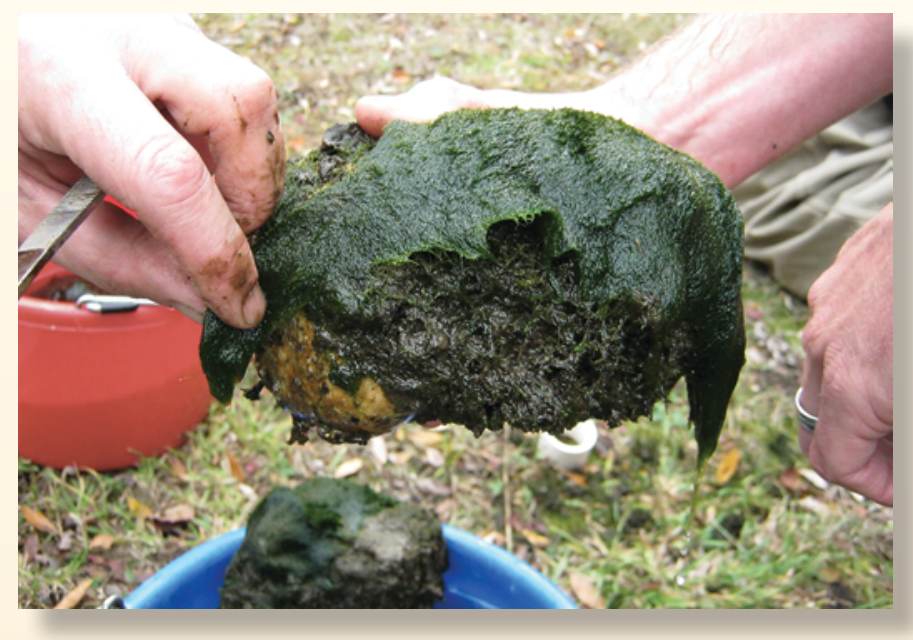

Cobble with Cladophora growth on top of moss at site A-R3D, October 2011.

\section{Is the Algal Growth in Fish Creek Typical for a Stream of its Size and Geographic Location?}

The greenish hue of Fish Creek's streambed is due to a variety of aquatic plants, including moss, vascular aquatic plants, and algae (microalgae, which is the thin slimy film on the rocks, and macroalgae, which is large algae such as the filamentous Cladophora). Samples of algae were collected and the quantity and distribution of aquatic plants were measured three times per year during 2007-11. Algal samples were analyzed for taxonomy and chlorophyll- $a$, which is a pigment used in photosynthesis. When comparing the amount of algae in Fish Creek (determined using chlorophyll- $a$ as an indicator) to other streams in the area, Fish Creek was atypical; concentrations of chlorophyll- $a$ at regularly sampled sites with perennial flow averaged more than 200 milligrams per square meter $\left(\mathrm{mg} / \mathrm{m}^{2}\right)$, whereas concentrations in other streams in the area generally range from 1.1 to $16 \mathrm{mg} / \mathrm{m}^{2}$ (Eddy-Miller and others, 2010a, b). In addition to the algal growth in the stream, other aquatic plants are found in large quantities as well. The high summertime growth of a combination of macroalgae, in particular Cladophora, vascular aquatic plants, and moss, also is atypical because microalgae typically is the predominant aquatic plant in other streams in the area.

Fish Creek always has algae present even during the middle of winter. Because Fish Creek typically is ice free in the winter, sunlight still reaches the streambed, allowing aquatic plants to continue photosynthesizing, albeit at a lower level of productivity in winter. The stable cobble and large gravel substrate in Fish Creek provides excellent attachment points for vascular aquatic plants, algae, and moss. This setting allows rapid growth, and the abundance of aquatic plants increases quickly once conditions warm during the spring (Eddy-Miller and others, 2013).

\section{Are Nutrients Entering Fish Creek from Upstream Land Use?}

During 2007-11, samples were collected from Fish Creek and nearby groundwater, and analyzed for nitrate and orthophosphate, both key nutrients for plant growth. Generally, nitrate and orthophosphate concentrations were low in Fish Creek, and occasionally were not detected in the stream water (most commonly during August). These low concentrations may be due to their absorption by aquatic plant life during the summer growing season (Eddy-Miller and others, 2013). Concentrations of nitrate and orthophosphate were higher in the continuously discharging groundwater than in the stream, which warranted sampling and evaluating nitrate isotopes and dissolved nitrate concentrations in nearby groundwater to investigate if land-use activities in the area were affecting the water quality. The water-quality results, as well as an understanding of the groundwater and surface-water interaction, verified that nitrate is entering Fish Creek from groundwater, and that the source of nitrate found in both groundwater and Fish Creek commonly was from septic/sewage effluent or manure, or a mixed source (Eddy-Miller and others, 2013).

\section{What is the Quality of the Water in Fish Creek and the Health of its Biological Communities?}

Water-quality samples from Fish Creek indicated the water contains sufficient dissolved mineral concentrations, $\mathrm{pH}$, water temperature, and dissolved oxygen to sustain fish and benthic macroinvertebrates (aquatic insects and other organisms that live on the streambed). Water-quality samples are a snapshot in time, so the inhabitants of the stream commonly are sampled as long-term indicators of water quality, and their responses to degradation of water quality and habitat are documented, and thus macroinvertebrates were sampled twice per year during the 2007-11 study. Data for this study are available at http://wy.water.usgs.gov/projects/fishcreek/communities.htm.

Statistically significant seasonal differences were noted in the macroinvertebrate community. Taxa richness (a summary of the number of species present) and relative abundance of Ephemeroptera (mayflies), Plecoptera (stoneflies), and Trichoptera (caddisflies), known as EPT, which tend to be intolerant of water-quality degradation, decreased from April/May to August. Conversely, there was an increase in Diptera (true flies) and noninsects, particularly Oligochaeta (worms), that are more tolerant, during the same time period (Eddy-Miller and others, 2013). One reason for the change in macroinvertebrate communities between seasons might be the seasonal shift in aquatic plant communities. Larger aquatic plants (Cladophora, moss, and vascular aquatic plants) increase in the summer, and the amount of surface that the thin algal film has on rocks decreases. This thin film is what several species of Ephemeroptera and Trichoptera feed on.

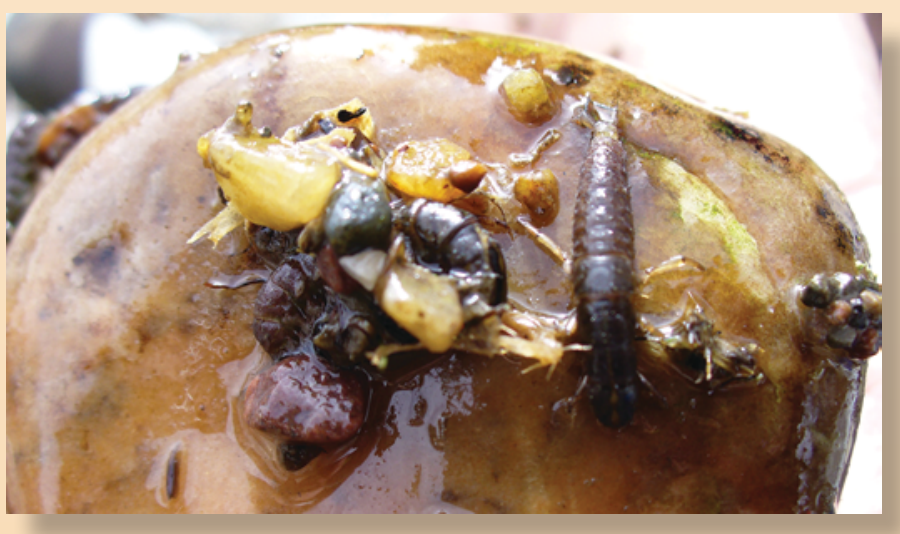

Trichoptera (caddisfly) larvae with retreats (center) and a larval case (right side of rock) at site A-Wck, April 2010. 
Additionally, comparisons of the macroinvertebrate communities between Fish Creek and nearby Cache Creek and Salt River (not shown on figures) indicate that although the Fish Creek macroinvertebrate community had some differences between seasons, the seasonal shift is not entirely attributable to a seasonal change caused by the emergence of nymphs (aquatic) to adults (terrestrial), because the other two sites maintained a greater presence of EPT in August than Fish Creek. The decrease in the EPT in August may be the result of the greatly increased growth of the larger aquatic plants in Fish Creek not seen at the other two stream sites. Overall, it appears that the water quality of Fish Creek is not directly affecting macroinvertebrates and fish; however, the numbers of the most sensitive macroinvertebrates are decreasing in the summer time when large aquatic plants have shown an increase in growth with changes in water quality.

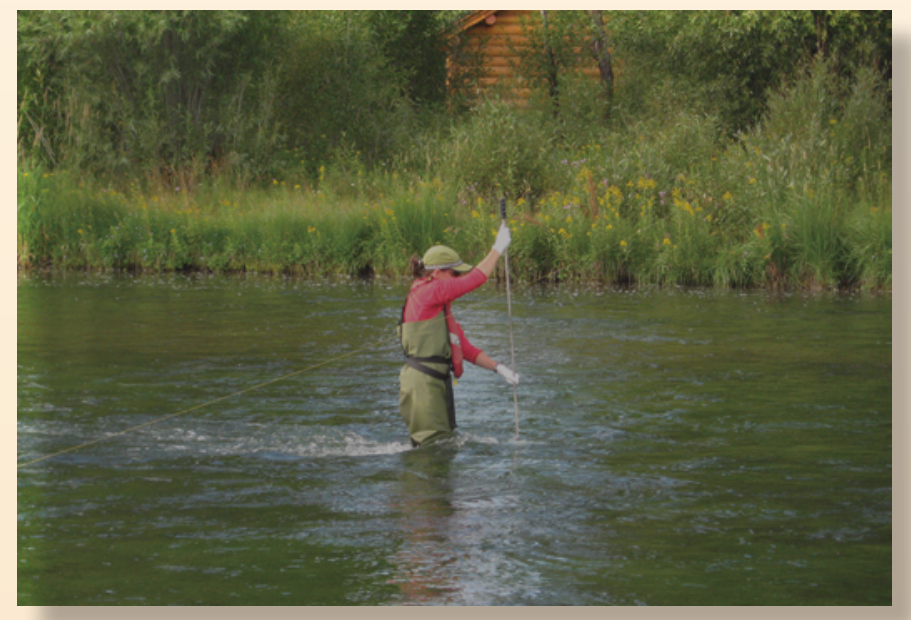

Water-quality sampling at site A-R7, August 2008.

\section{Fish Creek in the Future}

During the study period, dissolved nitrate concentrations were low in August (no detections in the water samples as a result of probable total absorption by the large growth of macroalgae, moss, and vascular aquatic plants), so it is possible that increased nitrate could result in increased growth of macrophytes, though this is unknown without a study focusing on this issue (Eddy-Miller and others, 2013). How increases in septic/sewage effluent, manure, or a mixed source would affect aquatic biologic issues in Fish Creek requires additional consistent, long-term monitoring of the stream, with concurrent data analysis and follow-up interpretation.

By Cheryl A. Eddy-Miller, ${ }^{1}$ Jerrod D. Wheeler, ${ }^{1}$ David A. Peterson, ${ }^{1}$ and Daniel J. Leemon ${ }^{2}$

${ }^{1}$ U.S. Geological Survey.

${ }^{2}$ Teton Conservation District.

\section{Selected References}

Eddy-Miller, C.A., Peterson, D.A., Wheeler, J.D., Edmiston, C.S., Taylor, M.L., and Leemon, D.J., 2013, Characterization of water quality and biological communities, Fish Creek, Teton County, Wyoming, 2007-2011: U.S. Geological Survey Scientific Investigations Report 2013-5117, 76 p. (Also available at http://pubs.usgs.gov/SIR/2013/5117/.)

Eddy-Miller, C.A., Peterson, D.A., Wheeler, J.D., and Leemon, D.J., 2010a, Characterization of water quality and biological communities, Fish Creek, Teton County, Wyoming, 2007-08: U.S. Geological Survey Scientific Investigations Report 2010-5188, 70 p. (Also available at http://pubs.usgs.gov/ $\operatorname{sir} / 2010 / 5188 /$.

Eddy-Miller, C.A., Peterson, D.A., Wheeler, J.D., and Leemon, D.J., 2010b, Characterization of Fish Creek, Teton County, Wyoming, 2004-08: U.S. Geological Survey Fact Sheet 2010-3075, 4 p. (Also available at http://pubs.usgs.gov/ $f_{S} / 2010 / 3075 /$.)

Eddy-Miller, C.A., and Wheeler, J.D., 2010, Chloride concentrations and stable isotopes of hydrogen and oxygen in surface water and groundwater in and near Fish Creek, Teton County, Wyoming, 2005-06: U.S. Geological Survey Data Series 518, 12 p. (Also available at http://pubs.usgs.gov/ $d s / 518 /$.

Eddy-Miller, C.A., Wheeler, J.D., and Essaid, H.L., 2009, Characterization of interactions between surface water and near-stream groundwater along Fish Creek, Teton County, Wyoming, by using heat as a tracer: U.S. Geological Survey Scientific Investigations Report 2009-5160, 64 p. (Also available at $h t t p: / / p u b s . u s g s . g o v /$ sir/2009/5160/.)

Nelson Engineering, 1992, Teton County westbank groundwater study: Jackson, Wyo., Nelson Engineering Report, 61 p.

U.S. Geological Survey, 2013, National Water Information System Web Interface-USGS 13016450 Fish Creek at Wilson, WY: accessed March 22, 2013, at http://waterdata.usgs.gov/ wy/nwis/uv? site_no $=13016450$.

Wheeler, J.D., and Eddy-Miller, C.A., 2005, Seepage investigation on selected reaches of Fish Creek, Teton County, Wyoming, 2004: U.S. Geological Survey Scientific Investigations Report 2005-5133, 20 p. (Also available at http://pubs.usgs. gov/sir/2005/5133/.)

\section{For More Information:}

USGS Wyoming Water Science Center Web site at http://wy.water.usgs.gov/projects/fishcreek/index.htm, or contact:

Cheryl A. Eddy-Miller, U.S. Geological Survey, 521 Progress Circle, Suite 6, Cheyenne, WY 82007, 307-775-9167,cemiller@usgs.gov

Dan Leemon, Teton Conservation District, P.O. Box, 1070, Jackson, WY 83001, 307-733-2110,dan@tetonconservation.org 